\title{
Preseismic Groundwater Ion Content Variations: Observational Data in Flowing Wells of the Kamchatka Peninsula and Conceptual Model
}

\author{
Galina Kopylova *(D) and Svetlana Boldina
}

Laboratory of Geophysical Research, Kamchatka Branch of the Geophysical Survey of the Russian Academy of Sciences (KB GS RAS), 683006 Petropavlovsk-Kamchatsky, Russia; boldina@emsd.ru

* Correspondence: gala@emsd.ru

Citation: Kopylova, G.; Boldina, S. Preseismic Groundwater Ion Content Variations: Observational Data in Flowing Wells of the Kamchatka Peninsula and Conceptual Model. Minerals 2021, 11, 731. https:// doi.org/10.3390/min11070731

Academic Editors: Andrea Pozzi and Gilberto Binda

Received: 28 May 2021

Accepted: 1 July 2021

Published: 6 July 2021

Publisher's Note: MDPI stays neutral with regard to jurisdictional claims in published maps and institutional affiliations.

Copyright: (c) 2021 by the authors. Licensee MDPI, Basel, Switzerland. This article is an open access article distributed under the terms and conditions of the Creative Commons Attribution (CC BY) license (https:// creativecommons.org/licenses/by/ $4.0 /)$.

\begin{abstract}
Repeated manifestations of hydrogeochemical anomalies in groundwater ion content variations before local strong earthquakes were recorded in three flowing wells of the PetropavlovskKamchatsky test site. A model of changes in chemical composition of groundwater is considered using observational data and modeling of two waters mixing with contrasting composition in a zone of increased permeability in aquifer. Hydrodynamic parameters of the model-relaxation time of water pressure impulses and the time of mixed water movement in aquifer and wellbore-can vary from days to hundreds of days in individual wells. These parameters determine the duration and morphological features of anomaly in mixed water from a well. Using observational data from self-flowing well M-1, an assessment was made of chemical composition and mineralization of two mixing waters and their ratio in mixed water under background conditions and during the preparation of earthquake on 2 March 1992, $M_{\mathrm{w}}=6.9$.
\end{abstract}

Keywords: flowing well; groundwater chemistry; earthquake; magnitude; precursor; Kamchatka Peninsula; conceptual model

\section{Introduction}

Observations of ion-salt groundwater composition in wells to search for hydrogeochemical earthquake precursors (HGCP) have been carried out for more fifty years in seismically active regions of the Earth, including Russia [1,2], Uzbekistan [3], China [4], India [5], Japan [6], Italy [7], Iceland [8] and other countries [9]. Such studies are carried out to obtain data on spatiotemporal manifestations of HGCP, depending on parameters of earthquakes and to assess the prospects for using HGCP for earthquake prediction. In addition to this important practical issue, certain attention is paid to methods for diagnosing hydrogeochemical anomalies in observed time series, mechanism and conceptual models of HGCP for improve system of hydrogeochemical observations.

The works [10-13] summarize the world data on HGCP. In these works, a small amount of such data was noted and the accumulation of new data on HGCP was put forward as a priority task for further research.

This paper presents data on preseismic groundwater ion content variations obtained as a result of hydrogeochemical observations in three flowing wells on the Kamchatka Peninsula (Figure 1) in 1986-1998. Brief information about hydrogeochemical observations on the Kamchatka Peninsula was given earlier in [11,14,15]. The review [2] provides the most complete data on hydrogeochemical precursors in wells of the Kamchatka Peninsula. At the same time, the main attention was paid to issues of the relationship between hydrogeological precursors and parameters of earthquakes as well as prospects of such observations for predicting earthquakes.

In this paper, using data on preseismic groundwater ion content variations and modeling, the possibility of constructing conceptual models of HGCP for individual wells is 
substantiated. A short summary of main ideas and modeling method with use a mathematical model of mixing two chemically contrasting waters in aquifer [16] were presented in [17] and in Russian in [18,19].

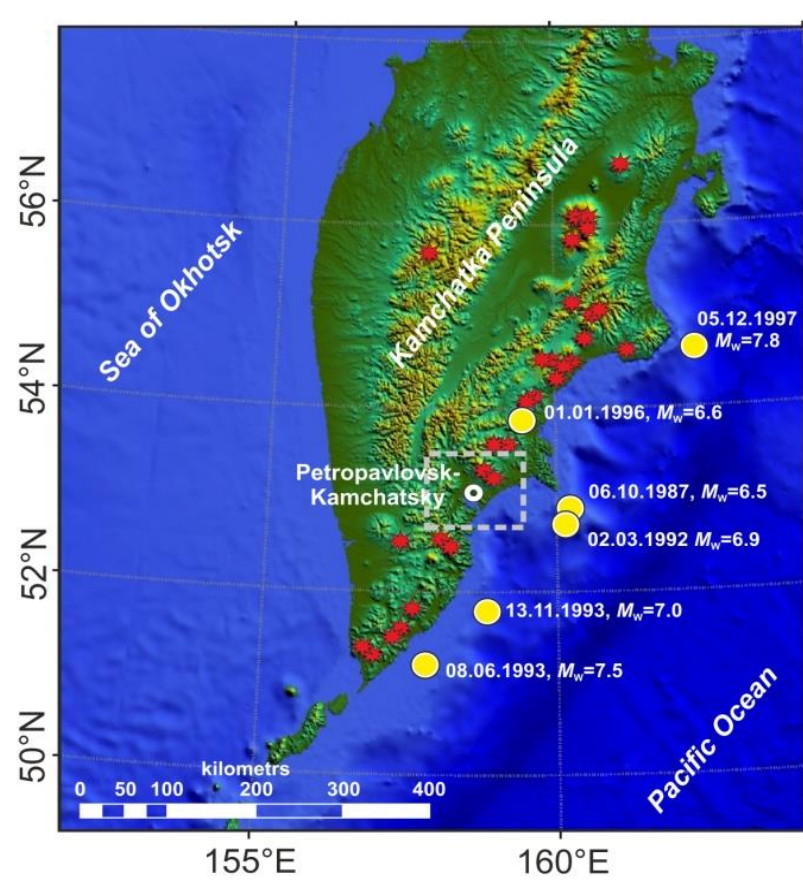

(a)

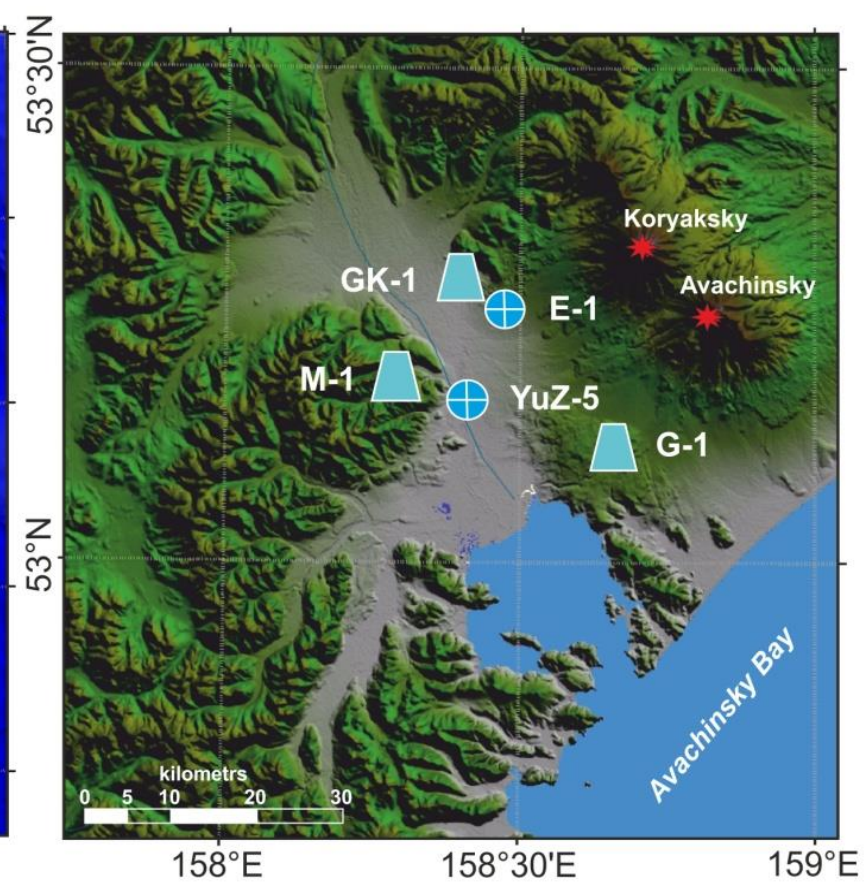

(b)

Figure 1. Layout of observation wells and earthquake epicenters: (a) earthquakes preceded by hydrogeochemical precursors; (b) observation wells at the Petropavlovsk-Kamchatsky test site. Designations: 1, flowing wells (Table 1); 2, piezometric wells; 3, active volcanoes; 4, earthquake epicenters (Table 2); 5, Petropavlovsk-Kamchatsky city; 6, Petropavlovsk-Kamchatsky test site in (a). 
Table 1. Observation wells, Kamchatka Peninsula.

\begin{tabular}{|c|c|c|c|c|c|c|c|c|}
\hline Well & Coordinates & $\begin{array}{c}\text { Depth, } \mathrm{m} \\
\text { Open Interval, } \mathrm{m}\end{array}$ & $\begin{array}{l}\text { Lithology: Age, } \\
\text { Composition }\end{array}$ & $\begin{array}{c}\text { Discharge Rate, } \\
q, \mathrm{dm}^{3} / \mathrm{s}\end{array}$ & $\begin{array}{c}\text { Water Temperature, } \\
{ }^{\circ} \mathrm{C}\end{array}$ & $\begin{array}{c}\text { Water Mineralization, } \\
\mathrm{g} / \mathrm{dm}^{3}\end{array}$ & Water Type & $\begin{array}{c}\text { Gas } \\
\text { Composition }\end{array}$ \\
\hline GK-1 & $\begin{array}{l}53.28^{\circ} \mathrm{N} \\
158.40^{\circ} \mathrm{E}\end{array}$ & $\begin{array}{c}1261 \\
400-1261 \\
\end{array}$ & $\begin{array}{c}\mathrm{Q}, \mathrm{N}, \mathrm{K}_{2} \\
\text { tuff, siltstone, shale }\end{array}$ & 0.1 & 16 & 10 & $\mathrm{Cl}-\mathrm{Na}-\mathrm{Ca}$ & $\begin{array}{l}\text { free gas, } \\
\mathrm{CH}_{4}-\mathrm{N}_{2}\end{array}$ \\
\hline G-1 & $\begin{array}{l}53.05^{\circ} \mathrm{N} \\
158.66^{\circ} \mathrm{E}\end{array}$ & $\begin{array}{c}2500 \\
1710-1719 \\
1750-1754 \\
1790-1799 \\
2415-2424\end{array}$ & $\begin{array}{c}\mathrm{Q}, \mathrm{K}_{2}, \\
\text { diorite, } \\
\text { shale }\end{array}$ & $<0.001$ & 10 & 12 & $\mathrm{Cl}-\mathrm{Na}$ & $\begin{array}{l}\text { free gas, } \\
\mathrm{CH}_{4}-\mathrm{N}_{2}\end{array}$ \\
\hline
\end{tabular}

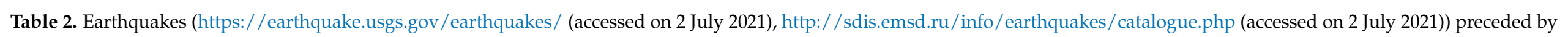
hydrogeochemical precursors in at least two flowing wells, Kamchatka Peninsula.

\begin{tabular}{|c|c|c|c|c|c|c|c|c|c|c|}
\hline No. & Date & $\begin{array}{l}\text { Earthquake } \\
\text { Epicenter }\end{array}$ & $\begin{array}{c}\text { Depth } H, \\
\text { km }\end{array}$ & $\begin{array}{c}\text { Magnitude } \\
M_{\mathrm{w}}\end{array}$ & $\begin{array}{c}\text { Earthquake Source } \\
\text { Length } \\
\text { (i) } \\
\text { km }\end{array}$ & $\begin{array}{c}\text { Earthquake } \\
\text { Epicentral Distance } \\
\text { to Wells } \\
d_{\mathrm{e}}, \mathrm{km} \\
\end{array}$ & $d_{\mathrm{e}} / L$ & $\begin{array}{c}\text { Specific Density of } \\
\text { Seismic Energy (ii) } \\
\qquad e, \mathrm{~J} / \mathrm{m}^{3}\end{array}$ & $\begin{array}{c}\text { Earthquake } \\
\text { Intensity on the } \\
\text { MSK-64 Scale } \\
\text { (iii) }\end{array}$ & $\begin{array}{c}\text { Wells (Precursor } \\
\text { Duration, } T_{1} / \text { Precursor } \\
\text { Lead Time, } T_{2} \text {, weeks) } \\
\text { (iiii) }\end{array}$ \\
\hline 1 & 06.10 .1987 & $52.86^{\circ} \mathrm{N} 160.23^{\circ} \mathrm{E}$ & 33 & 6.5 & 37 & 130-134 & $3.5-3.7$ & 0.1 & 5 & $\begin{array}{c}\text { GK-1 (30/30) } \\
\text { M-1 (4/4) }\end{array}$ \\
\hline 2 & 02.03.1992 & $52.76^{\circ} \mathrm{N} 160.20^{\circ} \mathrm{E}$ & 20 & 6.9 & 56 & $133-136$ & 2.4 & 0.2 & $5-6$ & $\begin{array}{c}\text { GK-1 (39/39), } \\
\text { M-1 (4/4) }\end{array}$ \\
\hline 3 & 08.06.1993 & $51.20^{\circ} \mathrm{N} 157.80^{\circ} \mathrm{E}$ & 40 & 7.5 & 103 & $220-233$ & $2.1-2.3$ & 0.3 & 5 & $\begin{array}{l}\text { GK-1 (4/4), } \\
\text { M-1 (4/21.5) }\end{array}$ \\
\hline 4 & 13.11.1993 & $51.79^{\circ} \mathrm{N} 158.83^{\circ} \mathrm{E}$ & 40 & 7.0 & 62 & $157-167$ & $2.5-2.7$ & $0.1-0.2$ & $5-6$ & $\begin{array}{l}\text { GK-1 (4/4), } \\
\text { M-1 (4/17) }\end{array}$ \\
\hline 5 & 01.01.1996 & $53.88^{\circ} \mathrm{N} 159.44^{\circ} \mathrm{E}$ & 0 & 6.6 & 41 & 95-108 & $2.3-2.6$ & $0.1-0.2$ & $4-5$ & $\begin{array}{c}\text { GK-1 (30/30), } \\
\text { M-1 (4/13), } \\
\text { G-1 (21.5/21.5) }\end{array}$ \\
\hline 6 & 05.12.1997 & $54.64^{\circ} \mathrm{N} 162.55^{\circ} \mathrm{E}$ & 10 & 7.8 & 139 & $305-314$ & $2.2-2.3$ & $0.3-0.4$ & $5-6$ & $\begin{array}{c}\text { GK-1 (21.5/21.5), } \\
\text { G-1 }(13 / 13)\end{array}$ \\
\hline
\end{tabular}

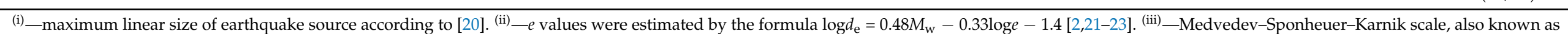

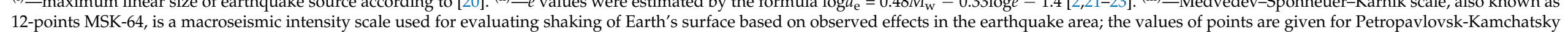

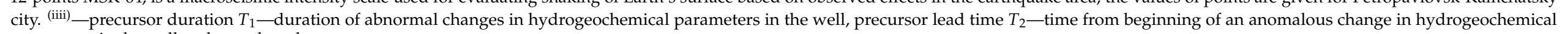
parameters in the well to the earthquake. 


\section{Observation Wells, Data on Hydrogeochemical Precursors and Earthquakes}

Kamchatka Peninsula (Figure 1a) is located at junction of Pacific Ocean Plate with the Eurasia and North America continental plates. Strong earthquakes often occur here, accompanied by destructive ground movements and tsunamis.

Kamchatka Branch of the Geophysical Survey of the Russian Academy of Sciences (KB GS RAS) conducts groundwater level and chemical composition monitoring at network of wells in the Petropavlovsk-Kamchatsky test site (Figure 1b) to study for hydrogeological precursors [1]. Data on flowing wells with repeated manifestations of hydrogeochemical precursors are presented in Table 1 and Figure 2.

During 1986-1998 water sampling at wells GK-1, M-1 and G-1 was carried out every three days. Water samples were analyzed for the concentration of anions $\mathrm{Cl}^{-}, \mathrm{HCO}_{3}^{-}$, $\mathrm{SO}_{4}{ }^{2-}$ and cations $\mathrm{Na}^{+}, \mathrm{K}^{+}, \mathrm{Ca}^{2+}, \mathrm{Mg}^{2+}$ with an accuracy of 2-10\% [24].

In the work are used data of hydrogeochemical observations obtained in 1986-1998, when the wells operated in undisturbed self-flowing regime. After 1999, the system of hydrogeochemical observations had changed due to increase in observation interval, a decrease in the set of determined parameters of groundwater composition and experiments with installation of equipment into wellbores violated natural hydrodynamic and hydrogeochemical regime of wells.

Data on strong local earthquakes preceded by hydrogeochemical precursors in at least two observation wells (Figure 1a, Table 2) were previously presented in [2]. Anomalous effects in ionic and gas composition of groundwater preceding earthquakes (Figure 1a, Table 2) clearly manifested themselves in time series of observations (Figure 3) and were statistically confirmed $[14,15,24-26]$.

\section{Manifestation of Hydrogeochemical Anomalies}

In well GK-1, decreases in chloride ion concentration were observed during one to nine months before six earthquakes. (Table 2, Figure 3a; diagram on the left). Before the earthquakes on 1 January 1996 and 5 December 1997, the decreases in chloride ion concentration were replaced by sharp increases within $4-5$ months. After earthquakes, the concentration of chloride ion in water always increases.

In the case of well GK-1, preseismic decrease in chloride ion concentration may indicate both a dilution of groundwater with low-mineralized near-surface waters and a decrease in the proportion of deep waters with increased mineralization in mixed water from the well.

An increase in dispersion and a change in average concentrations of free gases from well GK-1 were observed for two months before the 2 March 1992, earthquake (Figure 3a; right graph). Before earthquake, the concentrations of nitrogen and argon increased, while the concentrations of deep-seated gases methane, helium and carbon dioxide decreased. After the earthquake, there was an increase in the content of deep gases and a decrease in the content of atmospheric gases.

In well M-1, the concentration of bicarbonate ion decreased before five earthquakes (Table 2, Figure 3b). In four cases, a simultaneous increase in sulfate ion, calcium and sodium concentrations was found $[19,25]$.

Changes in the concentrations of chloride ion, sulfate ion, bicarbonate ion, as well as sodium and calcium were observed in well G-1 for 3-5 months before earthquakes on 1 January 1996 and 5 December 1997 (Figure 3c) [24].

The duration of precursory anomalies $\left(T_{1}\right)$ ranged from 4 to 39 weeks (Table 2), that is, approximately 1 to 9 months, and does not show any relationship with the magnitude of earthquakes (Figure 4a). For well M-1, there is an increase in lead time of hydrogeochemical anomaly $\left(T_{2}\right)$ in range of 1-5 months with an increase in magnitude of subsequent earthquake (Figure $4 b$ ). Perhaps this is due to high rate of water exchange in wellbore due to high water flow rate $\left(q=1.5 \mathrm{dm}^{3} / \mathrm{s}\right)$ compared to wells GK-1 and G-1 ( $q=0.1$ and $\left.<0.001 \mathrm{dm}^{3} / \mathrm{s}\right)$. 
Figure 5 from paper [2] demonstrates the relationship between preseismic hydrogeochemical anomalies and magnitude and epicentral distance to wells of subsequent earthquakes. Distribution of specific density of seismic energy $e[9,11,22,23]$ depending on earthquake parameters also shows in Figure 5. The $e$ value is considered as a parameter of earthquake impact in area of a well with preseismic hydrogeochemical anomaly.
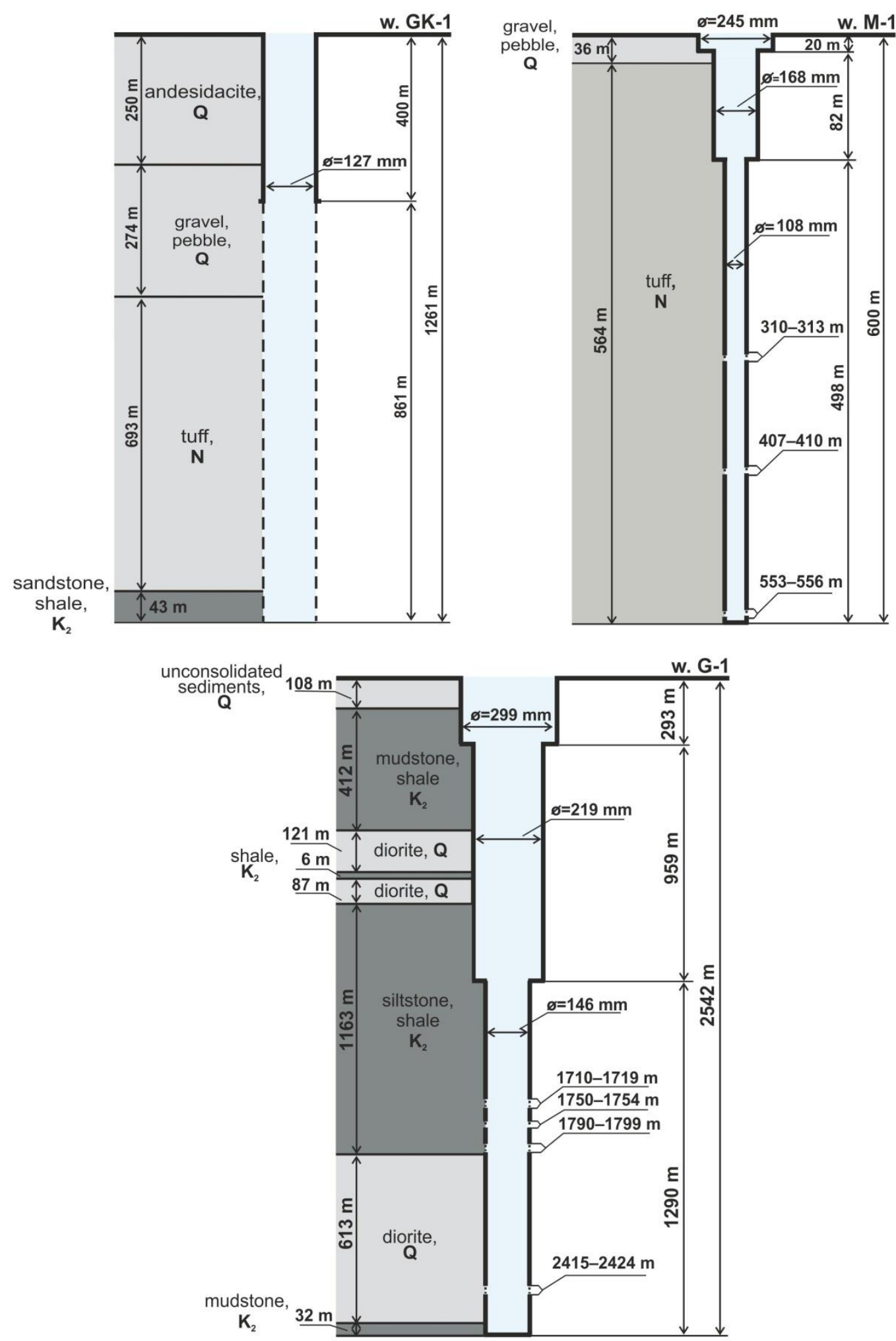

Figure 2. Observation wells. 
(a)
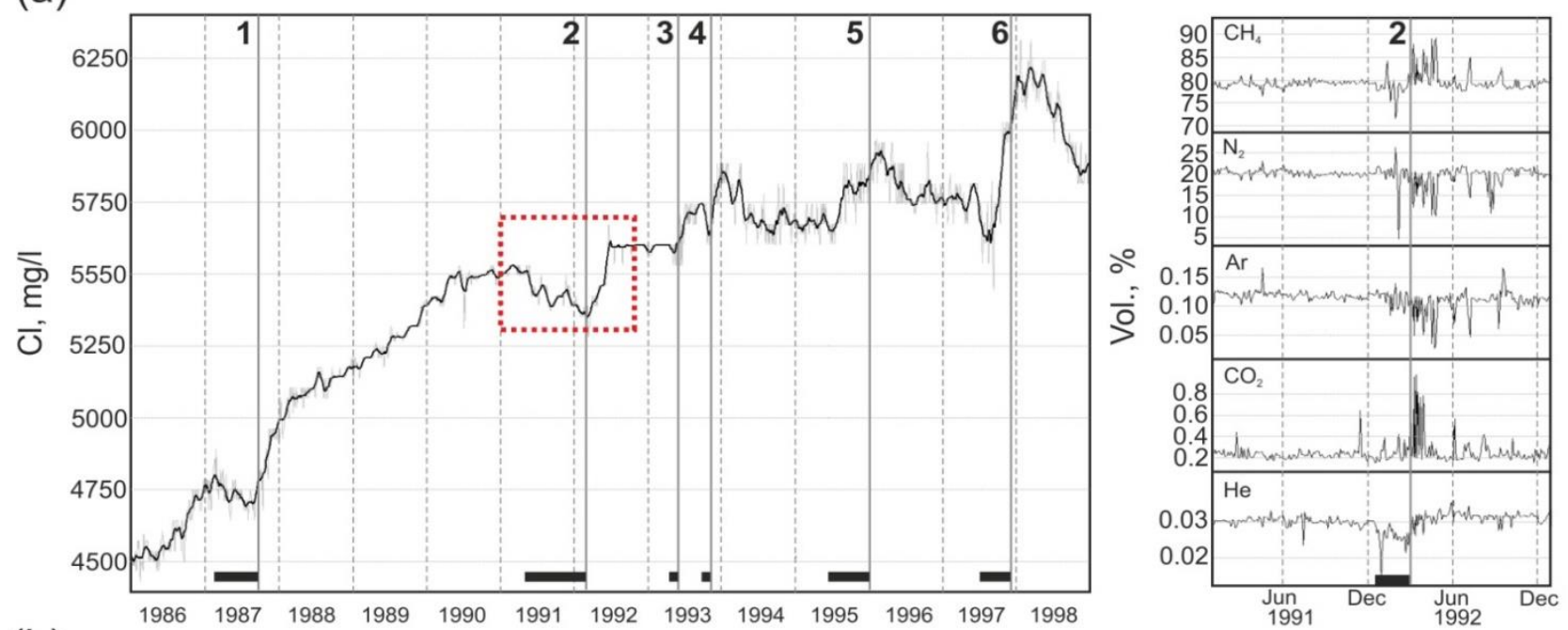

(b)
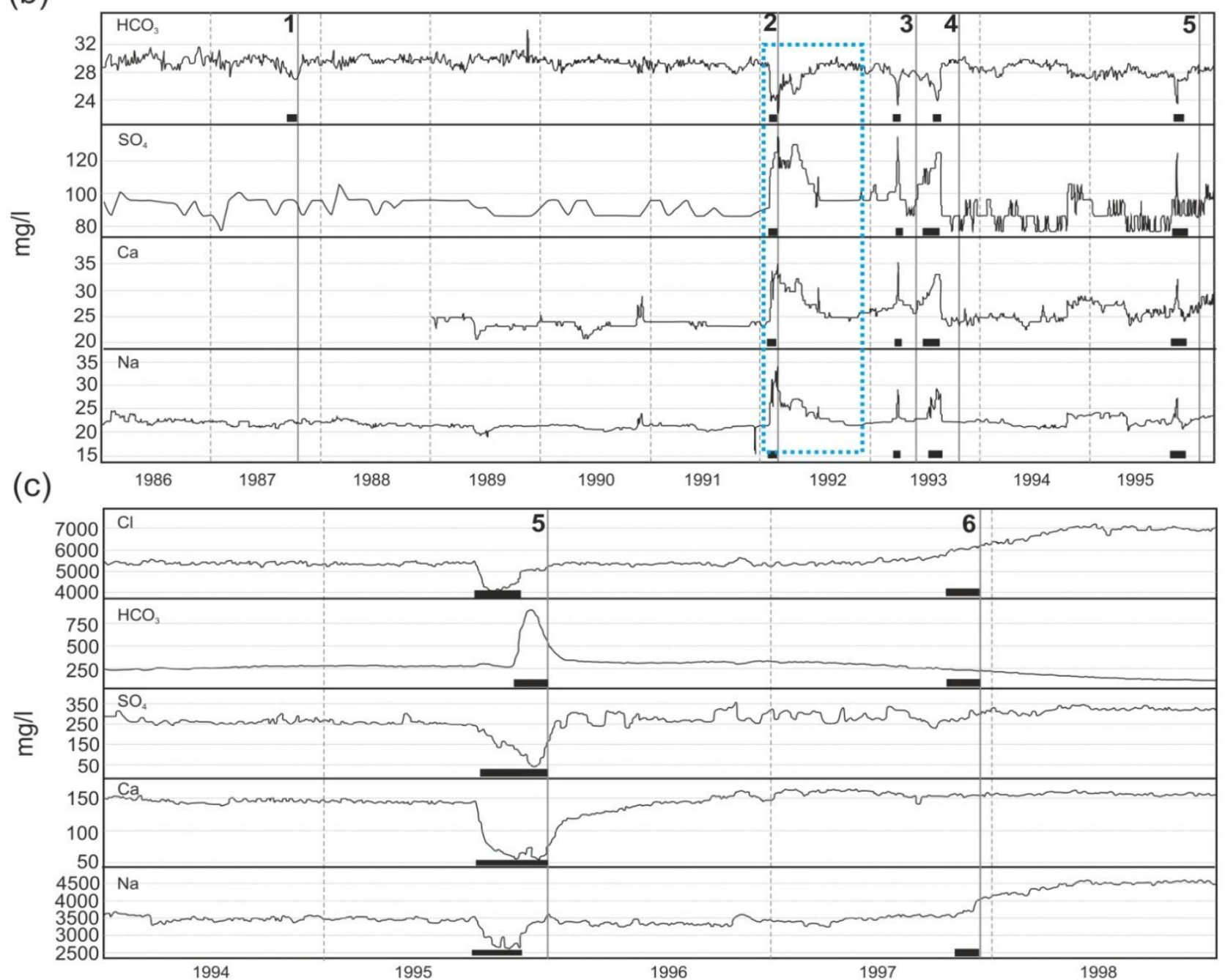

Figure 3. Anomalous effects (bold horizontal lines) in time series of groundwater ion and gas content variations from wells: (a) GK-1, (b) M-1, (c) G-1. Vertical lines show 1987-1997 earthquakes (Figure 1a), earthquake numbers correspond to Table 2. Red dashed rectangle highlights changes in $\mathrm{Cl}^{-}$concentration in water from well GK-1 and blue dashed rectangle highlights changes in $\mathrm{HCO}_{3}{ }^{-}, \mathrm{SO}_{4}{ }^{2-}, \mathrm{Ca}^{2+}$ and $\mathrm{Na}^{+}$concentrations in water from well $\mathrm{M}-1$ due to earthquake on $2 \mathrm{March}$ 1992 (Table 2). 


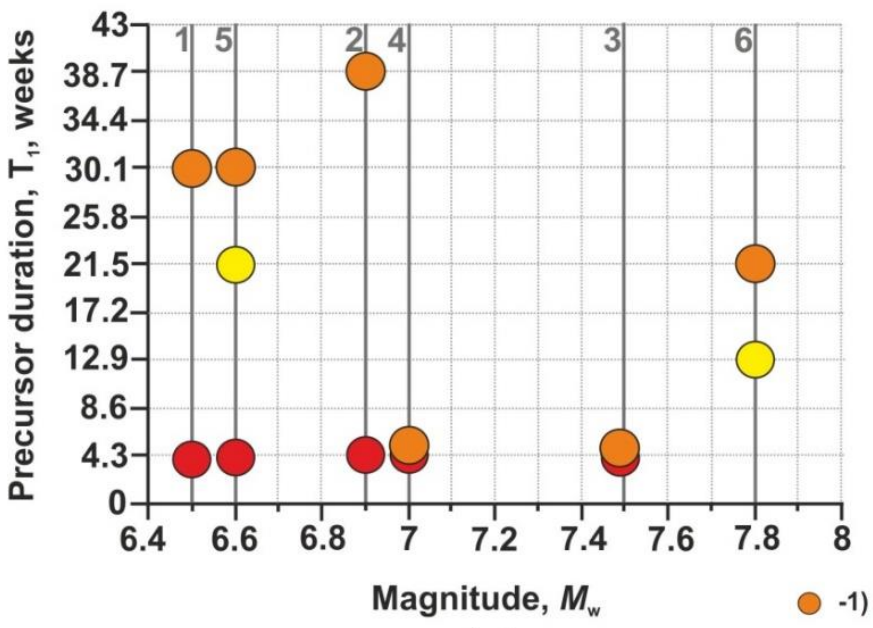

(a)

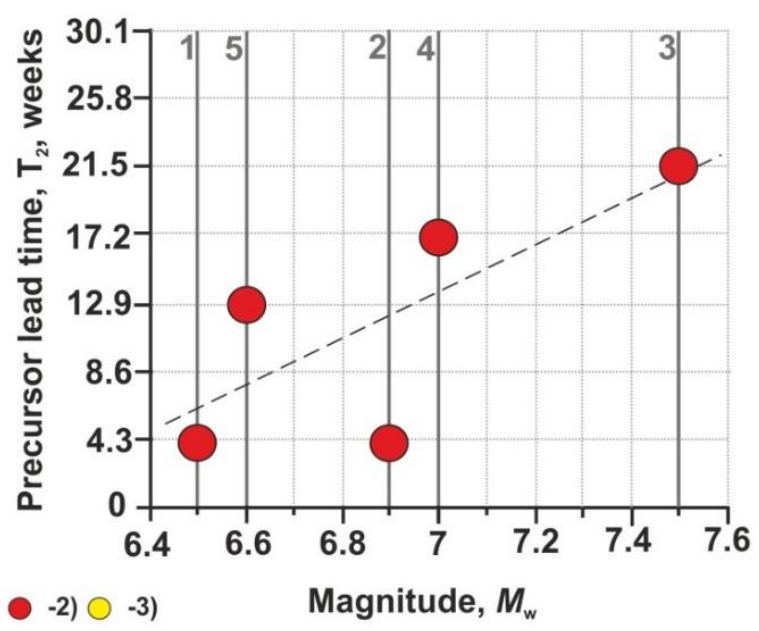

(b)

Figure 4. (a) Distribution of the precursor duration $\left(T_{1}\right)$ in observation wells: (1) GK-1, (2) M-1, (3) G-1, depending on magnitude $M_{\mathrm{w}}$ of earthquakes No. 1-6 in Table 2; earthquakes are shown with gray vertical lines. (b) Distribution of the lead time $\left(T_{2}\right)$ of preseismic anomalies in well M-1 (Figure 3b), depending on magnitude $M_{\mathrm{W}}$ of earthquakes No. 1-5 (linear correlation coefficient is 0.74$)$.

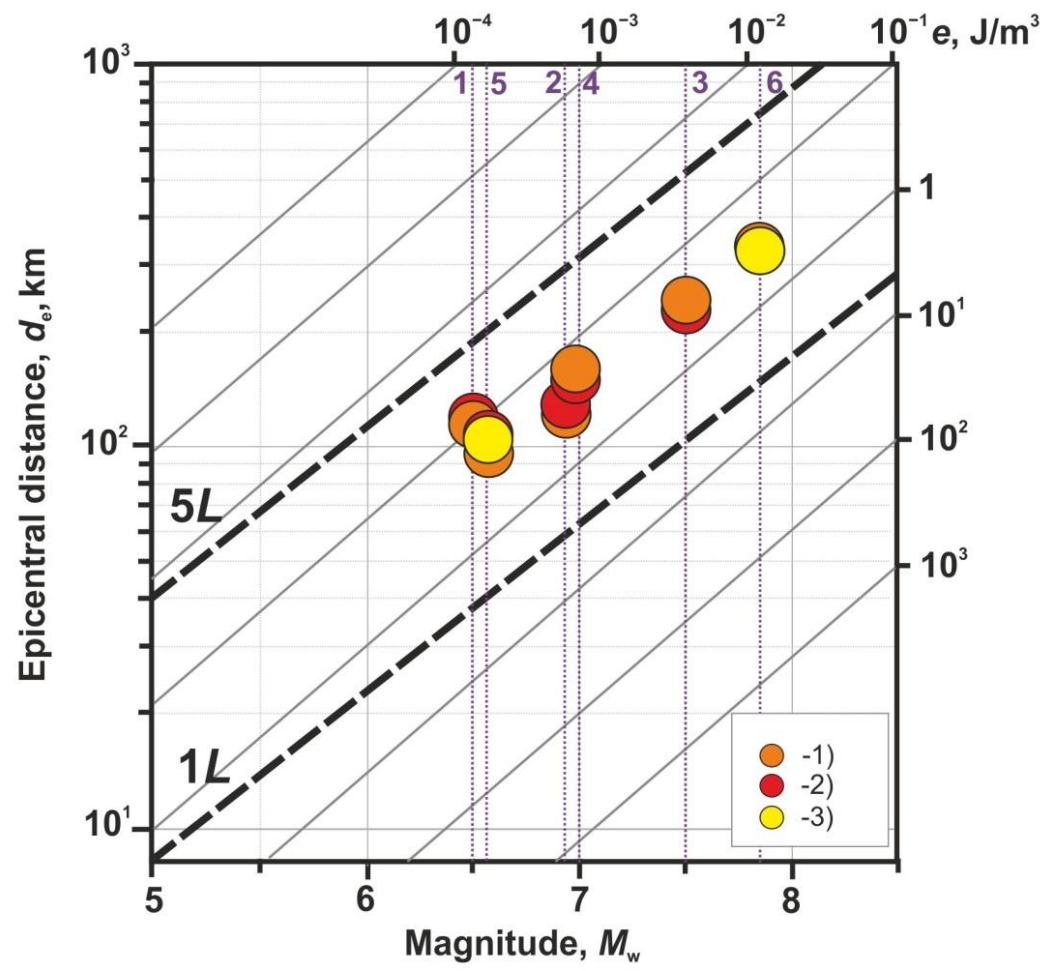

Figure 5. Distribution of precursory anomalies in ion content of underground water from flowing wells (1) GK-1, (2) M-1, (3) G-1 as function of earthquake parameters: magnitude $M_{\mathrm{w}}$, epicentral distance $d_{\mathrm{e}}$, and specific density of seismic energy $e$. Thin vertical dotted lines indicate earthquakes preceded by anomalies in ion content of underground water in two to three wells, earthquake numbers correspond to numbers in Table 2, Figure 3. Lines $1 \mathrm{~L}, 5 \mathrm{~L}$ show one and five linear sizes of earthquake source depending on magnitude $M_{\mathrm{w}}$ [20].

As follows from observational data (Table 2, Figure 3) and Figure 5, preseismic ion content variations appeared in two or three wells before earthquakes with $M_{\mathrm{w}}=6.5-7.8$, located at epicentral distances $d_{\mathrm{e}}=95-308 \mathrm{~km}$, or in range 2.1-3.7 of the maximum linear sizes of earthquake sources. These earthquakes were accompanied by shaking intensity of 
4-6 points on the MSK-64 scale in observation area. For such earthquakes, $e$ values were $0.1-0.4 \mathrm{~J} / \mathrm{m}^{3}$ (Table 2 ).

\section{Conceptual Model of Observed Hydrogeochemical Anomalies}

Data on hydrogeological precursors in wells of the Kamchatka Peninsula show the uniqueness of their manifestation in each observation well. Consequently, there is a need to develop and consistently refine the conceptual models of hydrogeological precursors for each individual well [2].

Conceptual models of preseismic variations in content of ions in groundwater from individual wells are based on the mechanism of their formation and corresponding functional dependencies. Possible mechanisms of hydrogeochemical anomalies due to preparation of earthquake are considered in detail in [10]. As a result of considering five possible mechanisms using data of laboratory experiments and routine observations, the author came to conclusion the mixing waters of different chemical composition is the most universal model for explaining anomalies in groundwater composition.

Let us note the difficulties of experimental and theoretical verification of assumptions about the mechanisms of hydrogeochemical precursors, primarily due to insufficient providing of the necessary complex of physicochemical parameters of groundwater. To build adequate models of hydrogeochemical precursors in flowing wells, it is necessary to take into account all macrocomponents of the chemical composition of water (anions and cations), gas composition, $\mathrm{pH}$, temperature and hydrodynamic parameters of groundwater (pressure and flow rate). In the absence of this set of observed parameters, there are significant uncertainties in the hydrogeochemical system behavior during the preparation of an earthquake.

\subsection{Issues of Hydrogeochemical Anomalies Modeling}

Changes in chemical composition of water from considered wells before earthquakes (Figure 3) can occur as a result of mixing of waters with different chemical content. Such a mixing can occur when hydrodynamic conditions in aquifer change or when the fracture-pore capacity of aquifer changes, as well as when the conditions for interaction of groundwater and rocks change during preparation of earthquake. In previous publications $[17,19,27]$, we considered these probable mechanisms of hydrogeochemical anomalies in wells, giving preference to mechanism of changing the mixing conditions of contrasting waters in aquifers. This idea of the leading role of the mixing mechanism in the formation of hydrogeochemical anomalies caused by earthquakes is in good agreement with cited works of other researchers.

When creating a model of anomalies in ion content variations in groundwater from individual wells developing in real time it is necessary to consider local geological and hydrogeological conditions and technical features of observations. For each observational well is necessary to estimate the volume of water in wellbore $\left(V, \mathrm{~m}^{3}\right)$ and discharge time as a result of water self-flowing $\left(T=0.001 V / Q, \mathrm{~s}\right.$, here $Q-$ flow rate, $\left.\mathrm{dm}^{3} / \mathrm{s}\right)$. The volume of water in the wellbore usually ranges from units to tens of $\mathrm{m}^{3}$, the flow rate ranges from $n \times 0.01 \mathrm{dm}^{3} / \mathrm{s}$ to $n \times 0.1-n \mathrm{dm}^{3} / \mathrm{s}$, here $n=1,2, \ldots, 9$. Thus, discharge time $T$ can range from several hours to first years. The value $T$ needs to be considered at assessment of hydrogeochemical anomaly duration in water-bearing rocks connected with observational well, because such duration is approximately equal to or exceeds value $T$. For wells $\mathrm{M}-1$ and GK-1 considered below, the values of $V=7.3$ and $16.2 \mathrm{~m}^{3}$; the values of $T=1.0-1.6 \mathrm{~h}$ and 1.9 days. Therefore, for these wells the time of complete water exchange in wellbore can be neglected when constructing a model of anomaly in the ionic composition of groundwater. At the same time, for well G-1 with a water exchange time $T$ equal to first years, the building of such model by mixing waters with contrasting composition in water-bearing rocks is more complicated.

When creating a hydrogeochemical model of anomaly changes in basic cations and anions in water composition, it is necessary to take into account the sampling interval $(\Delta t)$, 
the relative error in chemical analysis of individual components of water composition $\left(\Delta_{\mathrm{i}}\right)$ and the error in chemical analysis of water composition in sample $(O)$.

Let $x_{\mathrm{i}}$-analytically determined concentration of $i$-th component of water composition, $\mathrm{mg} / \mathrm{L} ; \Delta_{\mathrm{i}}$-relative error of $x_{\mathrm{i}}$ determination, \%. In this case, the concentration of the component $X_{\mathrm{i}}$ can take many values in range

$$
X_{\mathrm{i}}=x_{\mathrm{i}} \pm 0.01 \Delta_{\mathrm{i}} \times x_{\mathrm{i}}
$$

Water in samples from wells is a slightly mineralized solution, consisting of water and positively and negatively charged ions ( $K^{+}$cations and $A^{-}$anions). When the concentrations of $A^{-}$and $K^{+}$are expressed in $\mathrm{mmol} / \mathrm{dm}^{3}$, the condition of electrical neutrality of the solution is

$$
\Sigma K^{+}{ }_{\mathrm{i}}=\Sigma A^{-}{ }_{\mathrm{j}}
$$

Formula (2) usually serves as a criterion for the correctness of chemical composition determining in selected water samples. The error in chemical analysis of water composition is determined by the ratio $O=\left|\Sigma K^{+}-\Sigma A^{-}\right| /\left|\left(\Sigma K^{+}+\Sigma A^{-}\right)\right| \times 100 \%$. Chemical analysis of water composition is considered as correct and can be used for intended purpose at $O \leq 5-10 \%$ depending on mineralization and complexity of chemical composition of water [28].

\subsection{Mathematical Model}

Hydrodynamic analysis of mixing two waters with different composition in a zone of increased permeability (conductivity) in water-bearing rocks for background and disturbed conditions was given for the first time in [16]. The authors applied the developed approach to explain postseismic changes in flow rate and electrical conductivity of water from the KAT well in Georgia. Further, in [18], this approach was applied to simulate postseismic changes in flow rate and chloride ion concentration in water of the Pinachevsky spring in the Kamchatka Peninsula. In mentioned publications, it was shown that, under disturbed conditions, the change in concentration of some indicator component (IC) in mixed water flowing from the well can be described by the dependence:

$$
\delta \sigma(t)= \pm \delta \sigma_{0} \frac{e^{\left(-t / t_{0}\right)}-e^{\left(-t / \tau_{0}\right)}}{\left(1-\tau_{0} / t_{0}\right) \times\left(\tau_{0} / t_{0}\right)^{t_{0} /\left(t_{0}-\tau_{0}\right)}}
$$

Here $\delta \sigma(t)$ —change in IC concentration in time $t, \mathrm{mg} / \mathrm{L} ; \pm \delta \sigma_{0}$-amplitude of IC concentration change during the anomaly development, $\mathrm{mg} / \mathrm{L}$, " + "-with an increase in the IC concentration, "positive anomaly," "-"-with a decrease in the IC concentration, "negative anomaly;" $t_{0}$-duration of pressure impulse relaxation in aquifer, days; $\tau_{0}-$ duration of the mixed water flow in aquifer and wellbore, days.

Parameters $t_{0}$ and $\tau_{0}$ characterize the disturbance of hydrodynamic state of wellaquifer system both during earthquake preparation (preseismic stage) and after the impact of seismic waves (postseismic stage). The $t_{0}$ and $\tau_{0}$ values can take on different values at the preseismic and postseismic stages.

When modeling the registered hydrogeochemical anomalies using (3), the $\delta \sigma_{0}$ value for each IC can be estimated by observational data. The $t_{0}$ and $\tau_{0}$ values are determined by selection with a minimum divergence between the model and observed data for IC or for all basic macrocomponents of water composition. At the same time, it is desirable that the $t_{0}$ and $\tau_{0}$ values be determined by choosing with a minimum discrepancy between the model and observed time series for all main macrocomponents of the water composition with distinct manifestations of anomalies.

The conceptual model of hydrogeochemical anomalies recorded in chemical composition of water from wells M-1 and GK-1 during the earthquake on 2 March 1992 (Figure 3a,b) are presented below. 


\subsection{Modeling of Hydrogeochemical Anomalies with Use the above Approach}

Well M-1 with a depth of $600 \mathrm{~m}$ opens fractured-vein groundwater in Miocene tuffs in intervals 310-313, 407-410 and 553-556 m (Figure 2). Water-bearing rocks are characterized by ubiquitous propylitization and fracturing.

Hydrogeochemical anomaly in water from well M-1 manifested in increase of water mineralization by $30 \%$ and in change of hydrogeochemical water type due to relative increase of $\mathrm{SO}_{4}{ }^{2-}$ and decrease of $\mathrm{HCO}_{3}{ }^{-}$concentrations (Figure $3 \mathrm{~b}$; blue rectangle). The chemical composition of water corresponded to Formulas: $\mathrm{M}_{0.19}\left(\mathrm{SO}_{4} 78 \mathrm{HCO}_{3} 20\right) /(\mathrm{Ca} 56$ $\mathrm{Na} 44$ ) - in background conditions, that is, before precursor anomaly; $\mathrm{M}_{0.25}\left(\mathrm{SO}_{4} 87 \mathrm{HCO}_{3}\right.$ 11)/(Ca $55 \mathrm{Na} 45)$ - at extreme stage of precursor anomaly; anion and cation concentrations are expressed in $\%-\mathrm{mmol} / \mathrm{dm}^{3}, \mathrm{M}_{0.19}$ is water mineralization, $\mathrm{g} / \mathrm{dm}^{3}$. Errors in chemical analyzes of individual water samples were $O=1-6 \%$. Relative errors in determining the concentration of individual macrocomponents $\Delta_{i}=2-10 \%$ [29].

Figure 6 shows changes in concentrations of macrocomponents and results of calculations according to (3), taking into account the errors of chemical analysis of each component $\Delta_{\mathrm{i}}$ according to (1). Satisfactory agreement between the model and observed data of four parameters was obtained for values $t_{0}=20$ days and $\tau_{0}=50$ days.
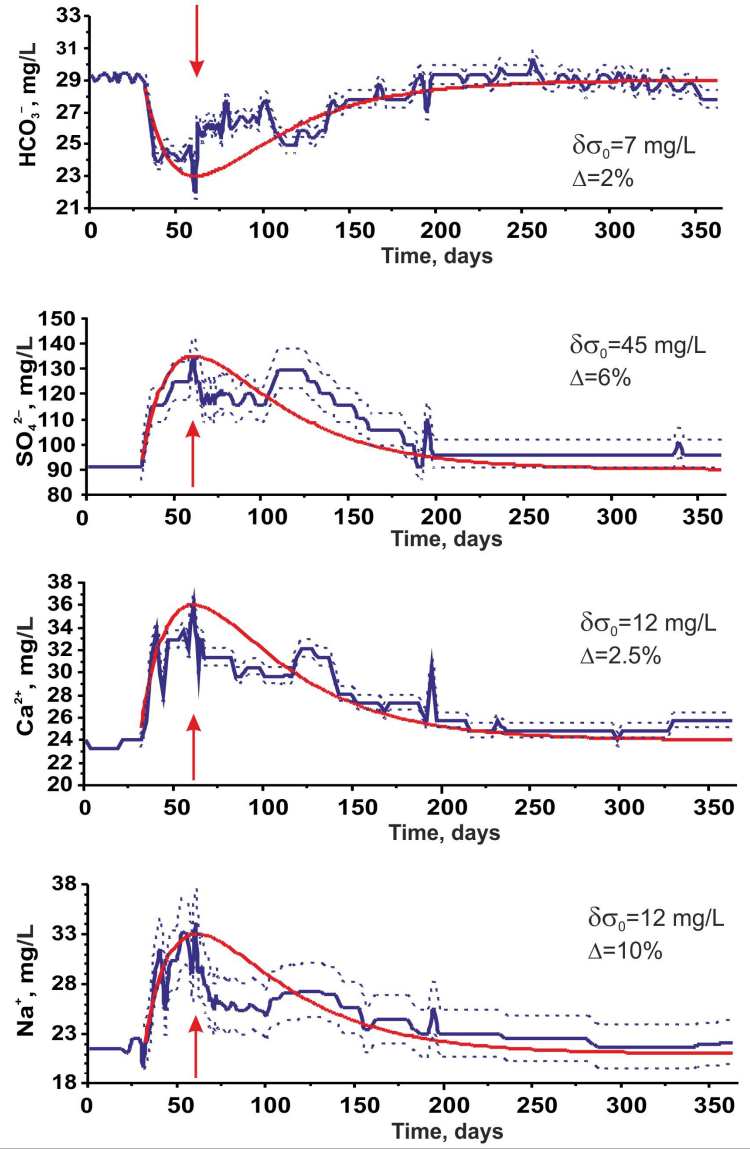

(a)
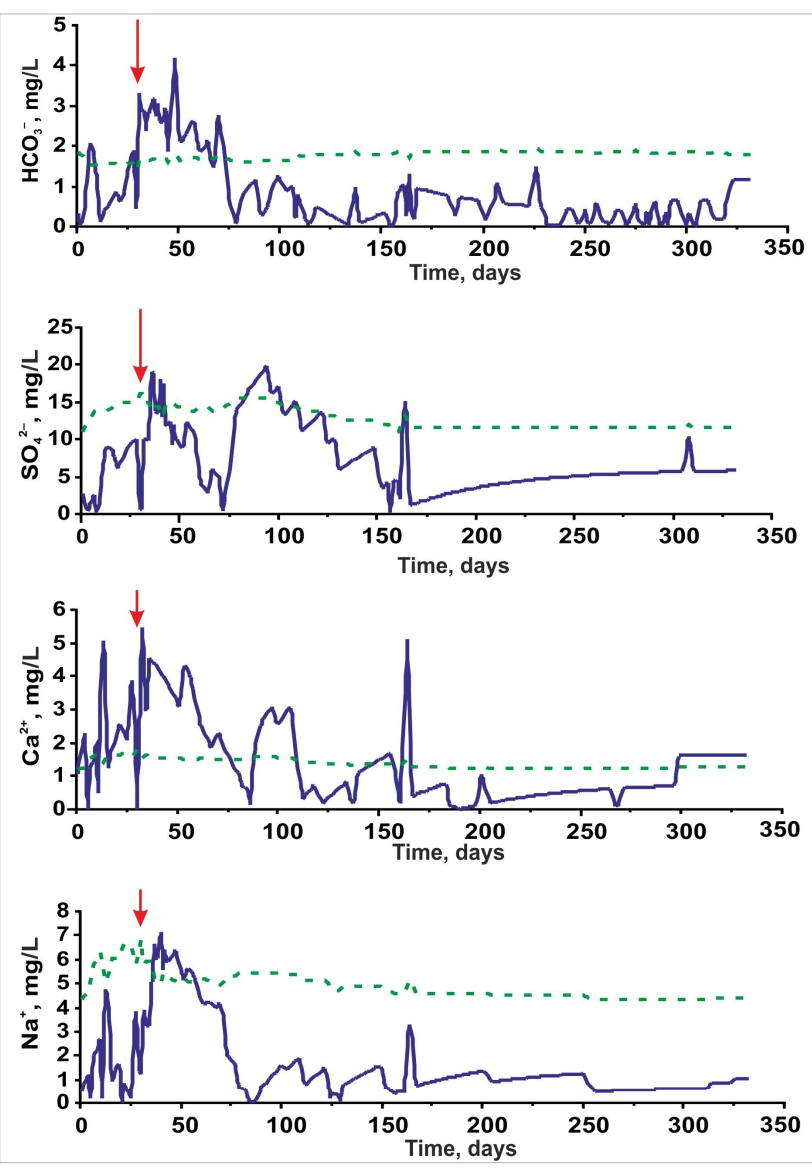

(b)

Figure 6. (a) Changes in $\mathrm{HCO}_{3}{ }^{-}, \mathrm{SO}_{4}{ }^{2-}, \mathrm{Ca}^{2+}, \mathrm{Na}^{+}$concentrations in water from well $\mathrm{M}-1$ due to earthquake on $2 \mathrm{March}$ 1992 (earthquake moment-red arrow) and results of calculations according to (3) at $t_{0}=20$ days and $\tau_{0}=50$ days. Blue lines-observational data; blue dotted lines-interval of concentration taking into account the error of determination $\Delta_{i}$ according to (1); red lines—calculated concentrations; $\delta \sigma_{0}$-amplitude of precursor anomaly. (b) Changes in the absolute values of residuals between the measured concentrations and calculated values (blue lines) in comparison with the double error $\Delta_{\mathrm{i}}$ in determining each concentration value (green dashed line). 
As seen in Figure $6 b$, there is some divergence between the model and observed data after earthquake for about first tens of days. The most plausible reason for this effect is superposition of seismic shaking on the development of anomaly due to preparation of earthquake. Seismic shaking caused relative increase in $\mathrm{HCO}_{3}{ }^{-}$concentration and decreases in $\mathrm{SO}_{4}{ }^{2-}, \mathrm{Ca}^{2+}$ and $\mathrm{Na}^{+}$concentrations compared with the development of precursory anomaly (Figure 6a). Thus, changes in chemical composition of water at postseismic stage was opposite in comparison with the precursor effect.

Well GK-1 opens mineralized waters in the depth range of 400-1261 $\mathrm{m}$ in fractured Pliocene andesi-basaltic tuffs and Late Cretaceous sandstones (Table 1, Figure 2). The water chemistry from well GK-1 corresponds to Formula $\mathrm{M}_{10} \mathrm{Cl}$ 98/( $\left.\mathrm{Na} 68 \mathrm{Ca} 27\right)$.

At stage of earthquake preparation, the anomaly manifested in decrease $\mathrm{Cl}^{-}$concentration by $180 \mathrm{mg} / \mathrm{L}$ (Figure 3a; red rectangle) or by 3\% in relation to background concentration. At postseismic stage, the $\mathrm{Cl}^{-}$concentration increased (Figure 3a).

Before the earthquake, the amplitudes of the decrease in sodium and calcium concentrations did not exceed the range of their chemical determination, taking into account the relative error $\Delta_{\mathrm{i}}$. Such weak manifestation of the earthquake preparation in the variations of calcium and sodium did not allow the use of data on cations in modeling. Therefore, modeling was carried out only for changes in the concentration of $\mathrm{Cl}^{-}$(IC), separately for the preseismic and postseismic stages (Figure 7).

(a)

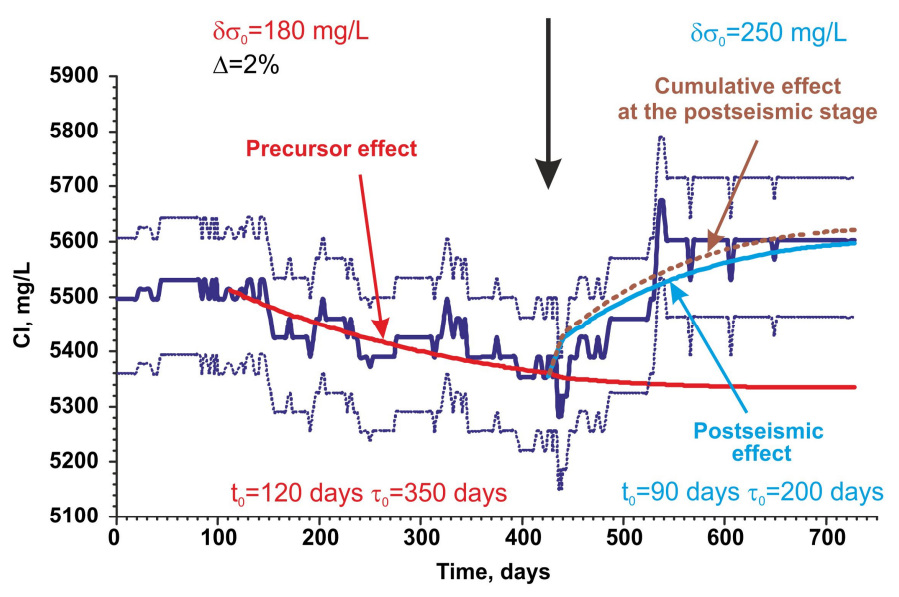

(b)

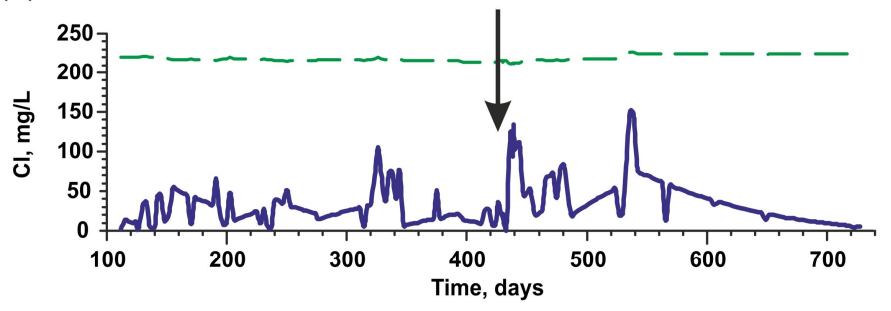

Figure 7. (a) Change in the $\mathrm{Cl}^{-}$concentration in water from well GK-1 due to the 2 March 1992 earthquake (earthquake moment-black arrow) and modeling results of precursory anomaly at $t_{0}=120$ days, $\tau_{0}=350$ days and postseismic anomaly at $t_{0}=90$ days, $\tau_{0}=200$ days according to (3). Blue line-observational data; blue dashed lines-intervals of $\mathrm{Cl}^{-}$concentration changes, taking into account the determination error of $\Delta_{\mathrm{Cl}}=2 \%$ according to (1); solid lines-calculated changes of $\mathrm{Cl}^{-}$concentration at precursory anomaly (red color) and postseismic anomaly (blue color); brown dashed line- the total effect of two processes at postseismic stage. (b) Change in absolute values of difference between the measured concentrations of $\mathrm{Cl}^{-}$and calculated values (blue solid line) in comparison with double error of determining each value of $\mathrm{Cl}^{-}$concentration (green dashed line). 
In this case, the absence of clear variations in $\mathrm{Na}^{+}$and $\mathrm{Ca}^{2+}$ concentrations reduce the validity of modeling results for well GK-1 compared with the M-1 well. At the same time, regular decreases in $\mathrm{Cl}^{-}$concentration before earthquakes and increases after earthquakes (Figure 3a) show dilution at preseismic stage and concentrating of groundwater in aquifer at postseismic stage.

\subsection{Chemical Composition of Mixing Waters in Aquifer of Well M-1}

We believe that the hydrogeochemical anomaly in well M-1 (Figure 6a) was formed by mixing two waters with different chemical composition in aquifer. Mixed water enters the wellbore in the area of three perforated sections (Table 1, Figure 2).

To estimate the compositions of mixing waters, a model of aquifer as a medium with double porosity [30] was assumed (Figure 8). In such an environment, the main flow of groundwater is carried out through a system of large interconnected fissures. Such fissures separate low permeable blocks containing water with other different composition and increased mineralization.

(a)

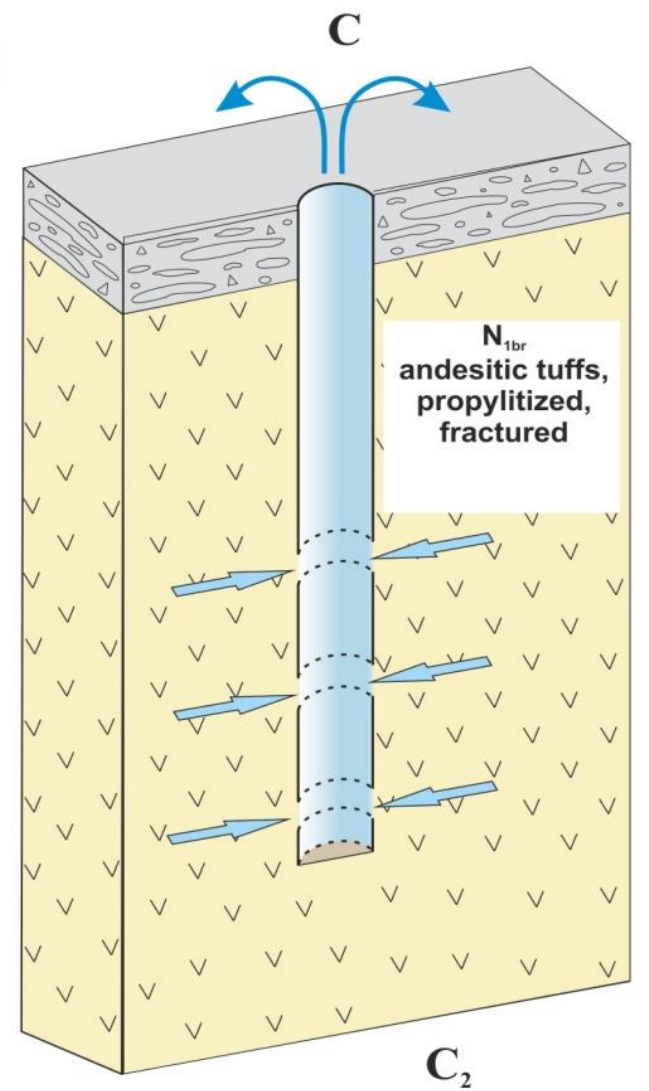

(b)

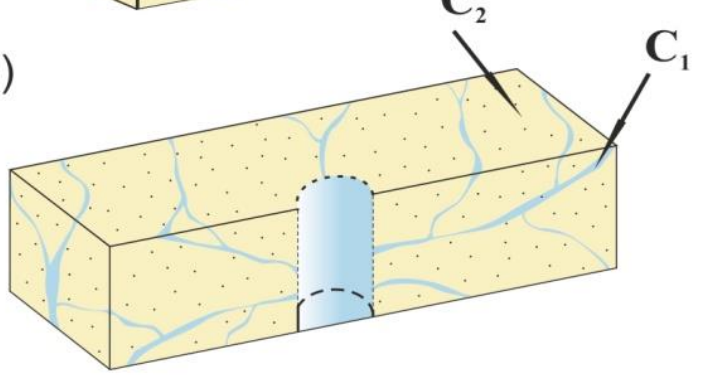

Figure 8. Diagrams of well M-1 (a) and aquifer as a medium with double porosity (b). Dashed lines in Figure (a) show the perforation sections of wellbore, horizontal arrows indicate the flow of mixed water into the wellbore, C-concentration of IC in mixed water flowing from the well; In Figure (b) shows $\mathrm{C}_{1}$-concentration of IC in water from "fissures", $\mathrm{C}_{2}-$ concentration of IC in water from "blocks". 
Under background conditions, the chemical composition of mixed water flowing out of the well is stable since there is a stationary hydrodynamic regime of water exchange between fissures and blocks. Under the earthquake preparation, the hydrodynamic conditions in aquifer are changed, and stationary regime of water exchange is disturbed. The change in hydrodynamic conditions is accompanied by a change in ratio of mixing waters, and changes in chemical composition of water outflowing from the well.

When calculating the compositions of two waters, the linear conditions of mixing in aquifer were taken: $\mathrm{C}=n \mathrm{C}_{1}+m \mathrm{C}_{2}, n+m=1$, here $\mathrm{C}$ is the concentration of IC in mixed water (Figure 8a), $C_{1}$ is the concentration of IC in "fissures", $C_{2}$ is the concentration of IC in "blocks" (Figure $8 \mathrm{~b}$ ), $n$ and $m$ are the proportions of water from "fissures" and "blocks" in mixed water. The background water exchange mode corresponds to $n>m$.

Boundary values of $C_{1}$ and $C_{2}$ concentrations (in $\mathrm{mg} / \mathrm{L}$ ) in mixing waters were estimated from observational data. - For $\mathrm{HCO}_{3}{ }^{-}--\mathrm{C}_{1}>31.2$ and $\mathrm{C}_{2}<22$, for $\mathrm{SO}_{4}{ }^{2-}-\mathrm{C}_{1}$ $<77$ and $\mathrm{C}_{2}>134.5$, for $\mathrm{Na}^{+}-\mathrm{C}_{1}<21$ and $\mathrm{C}_{2}>34.2$, for $\mathrm{Ca}_{2}{ }^{+}-\mathrm{C}_{1}<23$ and $\mathrm{C}_{2}>36$ were taken (Figure 6a). Additionally, the condition of electrical neutrality (2) of all three waters was accepted with an error of chemical analysis $O \leq 6 \%$. Under these constraints, the calculated compositions of miscible waters are given in Table 3 . The ratio between miscible waters under stationary regime were obtained for $n$ values in range $0.9-0.7$ and $m=0.1-0.3$. Under disturbed conditions, the ratio between miscible waters $n^{\prime}: m^{\prime}=(0.6-0.2):(0.4-0.8)$. When determining the proportion of two mixing waters at stage of anomaly $\left(n^{\prime}\right.$ and $\left.m^{\prime}\right)$, the calculated compositions of mixing waters were used. We also checked the stability of $n^{\prime}: m^{\prime}$ ratio for individual cations and anions and for all possible pairs of cation-cation, anion-anion, anion-cation.

Table 3. Estimated mineralization $\left(\mathrm{M}, \mathrm{g} / \mathrm{L}\right.$ ) and ion composition in $\%$ mmol of two mixing waters $\mathrm{C}_{1}$ and $\mathrm{C}_{2}$ (see Figures $6 \mathrm{a}$ and $8 \mathrm{~b}$ and text for explanations).

\begin{tabular}{|c|c|c|c|}
\hline $\begin{array}{l}\text { Ratio of the Mixing Waters } \\
\text { in Background Conditions } \\
n: m\end{array}$ & $\begin{array}{c}\text { Mineralization } M, g / L \text { and } \\
\text { ion Composition (in \% } \\
\text { mmol) in Water from } \\
\text { "Fissures" } C_{1}\end{array}$ & $\begin{array}{c}\text { Mineralization } M, g / L \text { and } \\
\text { ion Composition (in \% } \\
\text { mmol) in Water from } \\
\text { "Blocks" } C_{2}\end{array}$ & $\begin{array}{c}\text { Ratio of the Mixing Waters } \\
\text { at the Stage of Precursor } \\
\text { Anomaly } \\
n^{\prime}: m^{\prime}\end{array}$ \\
\hline 0.9:0.1 & $\begin{array}{c}\mathrm{M}_{0.17}\left(\mathrm{SO}_{4} 72 \mathrm{HCO}_{3} 25\right) / \\
(\mathrm{Ca} 53 \mathrm{Na} 46)\end{array}$ & $\begin{array}{c}\mathrm{M}_{0.37}\left(\mathrm{SO}_{4} 97 \mathrm{HCO}_{3} 2\right) / \\
(\mathrm{Ca} 66 \mathrm{Na} 34)\end{array}$ & 0.6:0.4 \\
\hline 0.87:0.13 & $\begin{array}{c}\mathrm{M}_{0.17}\left(\mathrm{SO}_{4} 71 \mathrm{HCO}_{3} 25\right) / \\
(\mathrm{Ca} 57 \mathrm{Na} 42)\end{array}$ & $\begin{array}{c}\mathrm{M}_{0.34}\left(\mathrm{SO}_{4} 96 \mathrm{HCO}_{3} 3\right) / \\
(\mathrm{Ca} 53 \mathrm{Na} 46)\end{array}$ & $0.5: 0.5$ \\
\hline $0.8: 0.2$ & $\begin{array}{c}\mathrm{M}_{0.16}\left(\mathrm{SO}_{4} 71 \mathrm{HCO}_{3} 26\right) / \\
(\mathrm{Ca} 56 \mathrm{Na} \mathrm{43)}\end{array}$ & $\begin{array}{c}\mathrm{M}_{0.32}\left(\mathrm{SO}_{4} 90 \mathrm{HCO}_{3} 8\right) / \\
(\mathrm{Ca} 54 \mathrm{Na} 45)\end{array}$ & $0.2: 0.8$ \\
\hline $0.7: 0.3$ & $\begin{array}{c}\mathrm{M}_{0.14}\left(\mathrm{SO}_{4} 65 \mathrm{HCO}_{3} 31\right) / \\
(\mathrm{Ca} 56 \mathrm{Na} 43)\end{array}$ & $\begin{array}{c}\mathrm{M}_{0.30}\left(\mathrm{SO}_{4} 90 \mathrm{HCO}_{3} 8\right) / \\
(\mathrm{Ca} 55 \mathrm{Na} 44)\end{array}$ & $0.2: 0.8$ \\
\hline
\end{tabular}

The obtained results (Table 3) show the hydrocarbonate-sulphate sodium-calcium water with mineralization of $0.14-0.17 \mathrm{~g} / \mathrm{L}$ in "fissures" and sulphate-sodium-calcium water with mineralization of $0.30-0.37 \mathrm{~g} / \mathrm{L}$ in "blocks". The hydrogeochemical anomaly in the water from the well was caused by an increase in proportion of water from "blocks" and a decrease in proportion of water from "fissures". Seismic shaking caused a relatively short-term increase in proportion of water from "fissures" in outflowing water (Figure 6).

\section{Discussion and Conclusions}

1. On the Kamchatka Peninsula, hydrogeochemical anomalies were observed in three self-flowing wells for a period of one to nine months before six earthquakes with $M_{\mathrm{W}}=6.5-$ 7.8 at epicentral distances $\left(d_{\mathrm{e}}\right)$ of $80-300 \mathrm{~km}$ (Figures $1 \mathrm{~b}$ and 2, Table 1 ). These earthquakes were the most powerful seismic events and were accompanied by ground shaking with intensity four to six points on the MSK-64 scale. Seismic energy density during these events in the regions of wells $e=0.1-0.4 \mathrm{~J} / \mathrm{m}^{3}$ (Table 2). The hydrogeochemical anomalies before 
earthquakes were observed in the near and intermediate field zones of earthquake sources $\left(d_{\mathrm{e}} / L=2.1-3.7\right)$ (Table 2, Figure 5). Such anomalies were recorded under the conditions of an undisturbed (natural) mode of functioning of self-flowing wells and had obvious character of hydrogeochemical precursors (HGCP).

The data obtained on HGCP in the Kamchatka Peninsula and established relationships between the HGCP manifestations with parameters of earthquakes (Figure 5) can be useful in study of hydrogeochemical and hydrogeodynamic phenomena preceding strong earthquakes both in other seismic regions, and changes in geophysical fields associated with variations in water-saturated environment.

2. The demonstrated results of modeling hydrogeochemical anomalies in two selfflowing wells at the stage of earthquake preparation, as well as well as at the postseismic stage $[16,18]$, show the broad possibilities of the model of mixing waters with a contrasting chemical composition for explaining hydrogeochemical anomalies caused by earthquakes. According to the development of registered hydrogeochemical anomalies and (3), the parameters of disturbed hydrodynamic state of aquifer can be estimated: $t_{0}$ —relaxation time of pressure impulse and $\tau_{0}$-time of mixed water flow movement in aquifer and wellbore. The $t_{0}$ and $\tau_{0}$ ratios determine the morphology (form) of manifestations as well as durations of hydrogeochemical anomalies.

Using observational data and Formula (3), we have built models of hydrogeochemical precursors and postseismic anomalies for wells GK-1 (Figures 3a and 7) and M-1 (Figures $3 \mathrm{~b}$ and 6 ) in case of the earthquake on 2 March 1992. It was found that the parameters $t_{0}$ and $\tau_{0}$ can differ significantly for two considered wells, even with the same earthquake.

Theoretical calculations of changes in the concentration of indicator component IC according to (3) for various $t_{0}$ and $\tau_{0}$ values are presented in Figure 9. In the vertical axis, changes in the IC concentration in water are shown in fractions of maximum amplitude of anomaly $\left|\delta \sigma_{0}\right|$, taken as a unit.

When the values $t_{0}, \tau_{0}$ are small (Figure $9 \mathrm{a}$ ) and observation periodicity $\Delta t$ is a relatively large, the anomaly cannot be detected or the idea of its morphology will be distorted. For example, the hydrogeochemical anomaly in well M-1 ((Figures 3b and 6a) was classified by morphological characteristics earlier as "impulse" [25] or "intermittent" [31]. The reason for wrong judgment was "large" observation periodicity $\Delta t=3$ days, did not allow estimating correct form of the anomaly from time series. At the same time, the observation periodicity $\Delta t=3$ days turned out sufficient to detect the "bay-like" ("bayshaped") hydrogeochemical anomalies in chloride ion concentration in water from well GK-1 (Figures $3 a, 7$ and $9 \mathrm{c} ; t_{0}=120$ days, $\tau_{0}=350$ days) and postseismic changes in chloride ion concentration in water of the Pinachevsky spring $\left(t_{0}=34-64\right.$ days, $\tau_{0}=30-91$ days [18]).

The ratio between the amplitude of anomaly $\delta \sigma_{0}$ and the error of chemical analysis $\Delta_{\mathrm{i}}$ must also be taken into account in the practical identification of anomaly in the individual component changes of the water composition.

When

$$
\delta \sigma_{0} \leq\left|\left(\sigma_{2} \pm 0.01 \Delta_{\mathrm{i}} \times \sigma_{2}\right)-\left(\sigma_{1} \pm 0.01 \Delta_{\mathrm{i}} \times \sigma_{1}\right)\right|,
$$

Here $\sigma_{1}$ is the analytically determined concentration of IC in background conditions; $\sigma_{2}$ is maximal IC concentration at stage of anomaly, then in this case, the identification of hydrogeochemical anomaly in time series is not possible.

In the case,

$$
\delta \sigma_{0}>\left|\left(\sigma_{2} \pm 0.01 \Delta_{\mathrm{i}} \times \sigma_{2}\right)-\left(\sigma_{1} \pm 0.01 \Delta_{\mathrm{i}} \times \sigma_{1}\right)\right|,
$$

The hydrogeochemical anomaly can be identified in time series at a sufficient observation periodicity $\Delta t$. 
(a)
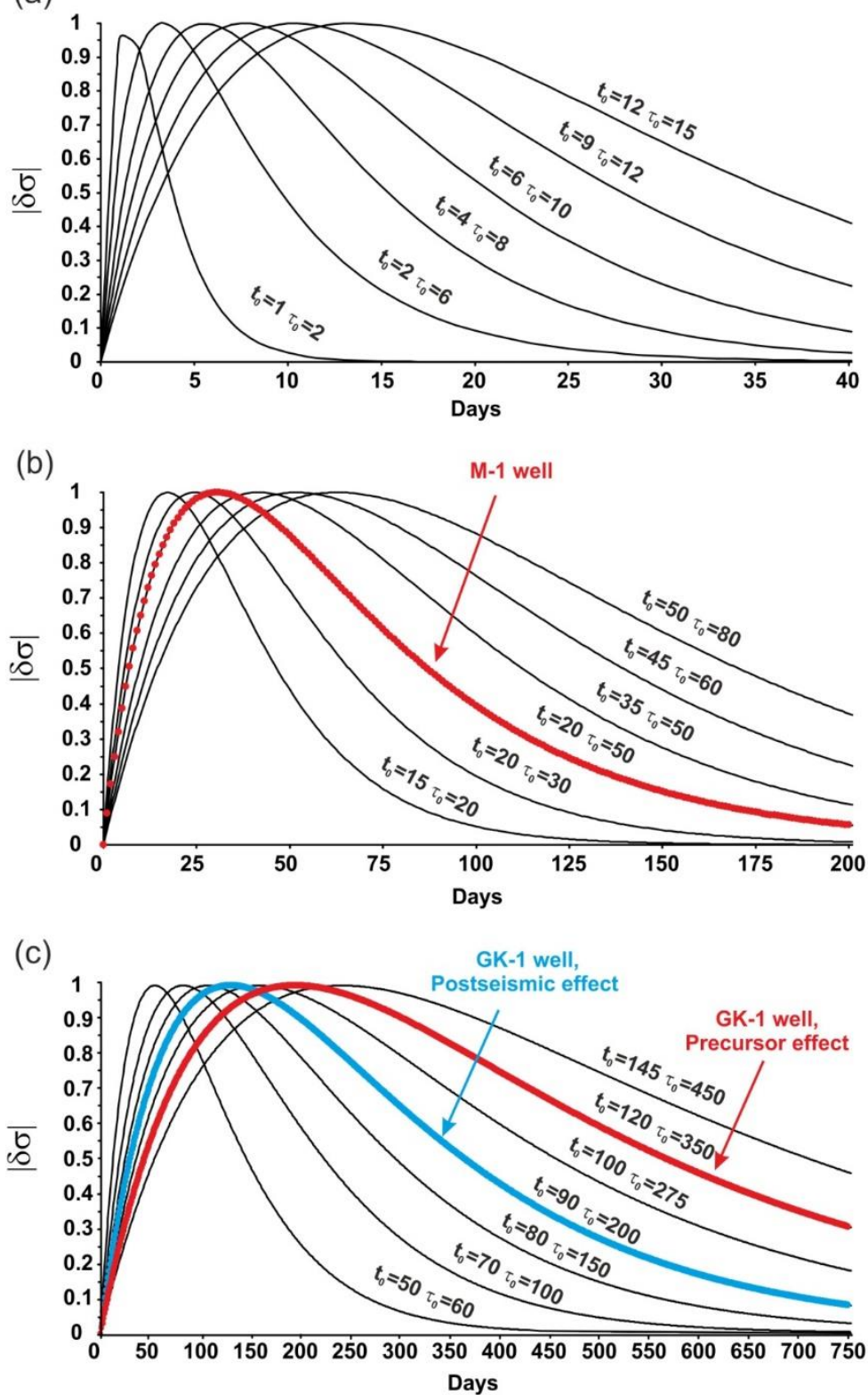

Figure 9. Calculated changes in concentration of the indicator component (IC) in underground outflowing water according to (3) at a relative value $\left|\delta \sigma_{0}\right|=1$ and different $t_{0}$ and $\tau_{0}$ values: $t_{0}=1-12$ days, $\tau_{0}=2-15$ days $(\mathbf{a}) ; t_{0}=15-50$ days, $\tau_{0}=20-80$ days $(\mathbf{b}) ; t_{0}=50-145$ days, $\tau_{0}=$ 60-450 days (c).

Suppose that the observation periodicity $\Delta t=3-10$ days and condition (5) is performed at the value $|\delta \sigma| \geq 0.7$ (Figure 9). In this case, most of the anomalies in Figure 9a,b either will not be observed, or they will stand out in time series in single bursts of values. Only anomalies with parameters $t_{0}$ and $\tau_{0}$ corresponding to Figure $9 \mathrm{c}$, can be diagnosed more or less adequately in time series obtained with the periodicity of observations $\Delta t=3-10$ days.

The above estimates, as well as the variety of hydrogeological conditions for the formation of the groundwater chemical composition, show the need to improve the methodology for recording hydrogeochemical phenomena in groundwater caused by earthquakes. It is necessary to introduce into practice of observations at flowing wells automated systems for high-precision registration not only the concentrations of individual IC but also integral indicators of water chemical composition, such as salinity and electrical conductivity with a frequency of at least one measurement per hour. 
3. By the example of well M-1, using the observational data, an adequate model of observed hydrogeochemical precursor of the earthquake on 2 March 1992 was created (Figure 6). The precursor anomaly was caused by a change in mixing two waters of different composition contained in fractures and in relatively weakly permeable blocks of water-bearing rocks (Figure 8).

The chemical compositions of mixing waters were estimated and it was shown that at the stage of earthquake preparation there was an increase of water inflow with increased mineralization from low-permeable blocks into fractured system (Table 3). The most probable mechanism of such a process is the improvement of hydraulic connection between fracture system and low-permeable blocks due to development of micro-fracturing in "blocks". An alternative mechanism changing the mixing conditions of two waters may be a non-uniform (localized) distribution of pore pressure variations in fractures and blocks at earthquake preparation and a redistribution of the flow rates of interacting water flows towards an increase of the flow from "blocks". In this case, the mixing ratio between the two different waters will also be disturbed, and respectively, the chemical composition of mixed water from the well will change.

It should be noted that in case of well M-1, the precursor anomaly was fixed in changes of all four macro components of water composition, both in anions and in cations. The construction of conceptual model was also facilitated by a favorable ratio between the periodicity of observations $\Delta t=3$ days and the duration of hydrogeochemical anomaly in changes of time series (approximately 26 days, 8 measurements).

Seismic shaking, causing dynamic variations in water pressure in the aquifer, was accompanied by a relative increase in the flow of low-mineralized water from fractures into wellbore, which is a zone of decreased water pressure due to constant discharge of underground water. Unfortunately, with the method used and periodicity of observations $\Delta t=3$ days, the reliable identification and modeling of postseismic changes of water composition from well M-1 is not possible. Attempts to simulate the relatively short-term variations in composition of water from well M-1 before 1987-1997 earthquakes, $M_{\mathrm{w}}=6.5-$ 7.8 (Figure 3b, No. 1, 3-5) were also unsuccessful due to obvious technical deficiencies of the observation system.

Author Contributions: Conceptualization, G.K; methodology, G.K. and S.B.; software, S.B.; validation, G.K. and S.B.; formal analysis, G.K.; investigation, G.K. and S.B.; resources, G.K. and S.B.; data curation, G.K.; writing—original draft preparation, G.K. and S.B.; writing—review and editing, G.K. and S.B.; visualization, S.B. and G.K.; supervision, G.K. All authors have read and agreed to the published version of the manuscript.

Funding: The work was supported by Ministry of Science and Higher Education of the Russian Federation (№ 075-00576-21). The data used in the work were obtained with large-scale research facilities "Seismic infrasound array for monitoring Arctic cryolitozone and continuous seismic monitoring of the Russian Federation, neighbouring territories and the world".

Data Availability Statement: The original contributions presented in the study are included in the article, further inquiries can be directed to the corresponding authors.

Conflicts of Interest: The authors declare that the research was conducted in the absence of any commercial or financial relationships that could be construed as a potential conflict of interest.

\section{References}

1. Kopylova, G.N.; Boldina, S.V. Hydrogeoseismological research in Kamchatka: 1977-2017. J. Volcanolog. Seismol. 2019, 13, 71-84. [CrossRef]

2. Kopylova, G.N.; Boldina, S.V. Hydrogeological Earthquake Precursors: A Case Study from the Kamchatka Peninsula. Front. Earth Sci. 2020, 8, 576017. [CrossRef]

3. Kopylova, G.N.; Yusupov, S.S.; Serafimova, Y.K.; Shin, L.Y.; Boldina, S.V. Hydrogeochemical earthquake precursors (on the example of areas of the Kamchatka peninsula, Russia, and the republic of Uzbekistan). Bull. Kamchatka Reg. Assoc. Educ. Sci. Cent. Earth Sci. 2020, 48, 5-20. (In Russian)

4. Zhou, Z.; Tian, L.; Zhao, J.; Wang, H.; Liu, J. Stress-Related Pre-Seismic Water Radon Concentration Variations in the Panjin Observation Well, China (1994-2020). Front. Earth Sci. 2020, 8, 596283. [CrossRef] 
5. Reddy, D.V.; Nagabhushanam, P. Search for hydraulic connectivity between surface reservoirs and surrounding aquifers in the Reservoir Induced Seismic environment (Koyna region, India) using hydrochemical and isotopic signatures. J. Seismol. 2016, 20, 43-62. [CrossRef]

6. Tsunogai, U.; Wakita, H. Precursory chemical changes in ground water: Kobe earthquake, Japan. Science 1995, 269, 61-63. [CrossRef]

7. Martinelli, G. Previous, current, and future trends in research into earthquake precursors in geofluids. Geosciences 2020, 10, 189. [CrossRef]

8. Skelton, A.; Liljedahl-Claesson, L.; Wästeby, N.; Andrén, M.; Stockmann, G.; Sturkell, E.; Mörth, C.M.; Stefansson, A.; Tollefsen, E.; Siegmund, H. Hydrochemical changes before and after earthquakes based on long-term measurements of multiple parameters at two sites in northern Iceland-A review. J. Geophys. Res. Solid Earth 2019, 124, 2702. [CrossRef]

9. Wang, C.-Y.; Manga, M. Water and Earthquakes. Lecture Notes in Earth System Sciences; Springer: Cham, Switzerland, $2021 ;$ p. 387. [CrossRef]

10. Thomas, D. Geochemical precursors to seismic activity. Pure Appl. Geophys. 1988, 126, 241-266. [CrossRef]

11. Wang, C.-Y.; Manga, M. Earthquakes and Water. Lecture Notes in Earth Sciences; Springer: Berlin, Germany, 2010; p. 225. [CrossRef]

12. King, C.-Y. Characteristics of a sensitive well showing pre-earthquake water-level changes. Pure Appl. Geophys. 2018, 175, 2411-2424. [CrossRef]

13. King, C.-Y.; Manga, M. Hydrological, geochemical and geophysical changes related to earthquakes and Slow-Slip events: Introduction. Pure Appl. Geophys. 2018, 175, 2407-2409. [CrossRef]

14. Biagi, P.F.; Ermini, A.; Cozzi, E.; Khatkevich, Y.M.; Gordeev, E.I. Hydrochemical precursors in Kamchatka (Russia) related to the strongest earthquakes in 1988-1997. Nat. Hazards 2000, 21, 263. [CrossRef]

15. Biagi, P.F.; Ermini, A.; Kingsley, S.P.; Khatkevich, Y.M.; Gordeev, E.I. Groundwater ion content precursors of strong earthquakes in Kamchatka (Russia). Pure Appl. Geophys. 2000, 157, 1359. [CrossRef]

16. Wang, R.; Woith, H.; Milkereit, C.; Zschau, J. Modeling of hydrogeochemical anomalies induced by distant earthquakes. Geophys. J. Int. 2004, 157, 717-726. [CrossRef]

17. Kopylova, G.; Boldina, S. Anomalies in Groundwater Composition Caused by Earthquakes: Examples and Modeling Issues. E3S Web Conf. 2019, 98, 01029. [CrossRef]

18. Kopylova, G.N.; Voropaev, P.V. Generation of postseismic anomalies in the chemical composition of thermal mineral water. Volkanologiya Seysmologiya 2006, 5, 42-48. (In Russian)

19. Kopylova, G.N.; Boldina, S.V. Anomalies in the chemical composition of underground water due to the 2nd March 1992 earthquake $\left(\mathrm{M}_{\mathrm{W}}=6.9\right)$, Kamchatka. Geofiz. Issled. 2012, 13, 39-49. (In Russian)

20. Riznichenko, Y.V. The source dimensions of the crustal earthquakes and the seismic moment. In Issledovaniya po Fizike Zemletryasenii (Studies in Earthquake Physics); Nauka: Moscow, Russia, 1976; pp. 9-27. (In Russian)

21. Wang, C.-Y. Liquefaction beyond the near field. Seismol Res. Lett. 2007, 78, 512-517. [CrossRef]

22. Wang, C.-Y.; Chia, Y. Mechanism of water level changes during earthquakes: Near field versus intermediate field. Geophys. Res. Lett. 2008, 35, L12402. [CrossRef]

23. Kopylova, G.N.; Boldina, S.V. Effects of seismic waves in water level changes in a well: Empirical data and models. Izv. Phys. Solid Earth 2020, 56, 530-549. [CrossRef]

24. Khatkevich, Y.M.; Ryabinin, G.V. Geochemical and ground water studies in Kamchatka in the search for earthquake precursors. Volkanologiya Seysmologiya 2006, 4, 34-42. (In Russian)

25. Kopylova, G.N.; Sugrobov, V.M.; Khatkevich, Y.M. Variations in the regime of springs and hydrogeological boreholes in the Petropavlovsk polygon (Kamchatka) related to earthquakes. Volkanologiya Seysmologiya 1994, 2, 53-70. (In Russian)

26. Kopylova, G.N.; Taranova, L.N. Synchronization signals in the variations of groundwater chemical composition in Kamchatka in relation to the strong $\left(M_{\mathrm{W}} \geq 6.6\right)$ earthquakes. Izvestiya Phys. Solid Earth 2013, 49, 577-586. [CrossRef]

27. Kopylova, G.N.; Guseva, N.V.; Kopylova, Y.G.; Boldina, S.V. The Chemical Composition of Ground Water in Observational Water Vents in the Petropavlovsk Geodynamic Test Site: The Classification and Effects of Large Earthquakes. J. Volcanol. Seismol. 2018, 12, 268-286. [CrossRef]

28. Laptev, F.F.; Sokolov, I.Y. Information on the Chemistry of Groundwater. Hydrogeologist's Handbook; Altovsky, M.E., Ed.; Gosgeoltekhizdat: Moscow, Russia, 1962; pp. 165-229. (In Russian)

29. Khatkevich, Y.M.; Ryabinin, G.V. Hydrogeochemical studies in Kamchatka. In tegrated seismological and geophysical studies of Kamchatka. In Kompleksnye Seismologicheskie i Geofizicheskie Issledovaniya Kamchatki (Multidisciplinary Seismological and Geophysical Studies in Kamchatka); Kamchatskij Pechatnyj Dvor: Petropavlovsk-Kamchatsky, Russia, 2004; pp. 96-112. (In Russian)

30. Barenblatt, G.I.; Zheltov, Y.P. On the basic equations of homogeneous fluids filtration in fractured rocks. Dokl. Acad. Sci. USSR 1960, 132, 545-548.

31. Ryabinin, G.V.; Khatkevich, Y.M. Hydrogeochemical factors preceded large earthquakes in Kamchatka: Identification algorithm and morphological analysis. Bull. Kamchatka Reg. Assoc. Educ. Sci. Cent. Earth Sci. 2009, 13, 107-122. (In Russian) 